\title{
Medika Kartika : Jurnal Kedokteran dan Kesehatan
}

\section{ARTIKEL PENELITIAN}

\author{
PERBANDINGAN DAYA HAMBAT EKSTRAK DAUN DAN BUAH JAMBU BIJI \\ (Psidium guajava) TERHADAP AKTIVITAS BAKTERI Enterococcus faecalis \\ (COMPARISON OF THE LEAF AND SEED JAMBU FRUIT EXTRACT (Psidium guajava) \\ ON Enterococcus faecalis ACTIVITIES) \\ $\underline{\text { Rachmi Fanani Hakim }}{ }^{1}$, Fakhrurrazi $^{1}$, Masnaini ${ }^{1}$ \\ ${ }^{1}$ Fakultas Kedokteran Gigi Universitas Syiah Kuala \\ Email korespondensi: rachmifananihakim@unsyiah.ac.id
}

\begin{abstract}
ABSTRAK
Enterococcus faecalis merupakan bakteri Gram positif fakultatif anaerob yang memiliki kemampuan untuk hidup dalam berbagai lingkungan. Baketi ini mampu bertahan dalam saluran akar sehingga menjadikan bakteri ini sering disebut menjadi penyebab terjadinya kegagalan perawatan saluran akar. Buah dan daun Jambu biji (Psidium guajava) memiliki kandungan flavonoid, tanin, minyak atsiri dan saponin. Kandungan tersebut mampu bertindak sebagai antibakteri. Tujuan Penelitian ini membandingkan pengaruh ekstrak daun dan buah jambu biji terhadap pertumbuhan bakteri Enterococcus faecalis. Penelitian ini merupakan eksperimental laboratorium dengan Post Test Only Control Group Design. Uji daya hambat dengan metode Difusi Cakram, menggunakan media Mueller Hinton Agar (MHA) dengan metode spread (sebar) dan teknik swab. Hasil dianalisis dengan uji one-way Anova kemudian dilanjutkan uji LSD. Hasil penelitian menunjukkan terdapat hambatan pertumbuhan Enterococcus faecalis setelah dipaparkan ekstrak daun dan buah jambu biji. Konsentrasi zona hambat bakteri meningkat dengan bertambahnya konsentrasi ekstrak. Diameter zona hambat yang terbentuk pada pemberian ekstrak daun jambu biji konsentrasi 25\%, 50\%, 75\% dan 100\% adalah 7,75 mm, 10,46 mm, 12,50 $\mathrm{mm}$ dan 15,13 $\mathrm{mm}$. Diameter rerata zona hambat yang terbentuk pada pemberian ekstrak buah jambu biji konsentrasi 25\%, 50\%, 75\% dan 100\% adalah 8,36 mm, 10,50 mm, 10,96 mm
\end{abstract}


Rachmi Fanani Hakim : Perbandingan Daya Hambat Ekstrak Daun ...

dan 15,10 mm. Kemampuan zona hambat konsentrasi daun jambu biji $100 \%$ hampir setara dengan kemampuan zona hambat buah jambu biji $100 \%$.

Kata kunci: Enterococcus faecalis, Ekstrak Daun jambu biji, Ekstrak Buah Jambu Biji

\section{ABSTRACT}

Enterococcus faecalis is a facultative anaerobic positive Gram bacteria that has the ability to live in a variety of environments. This bacteria is able to survive in the root canal so that makes this bacterium is often called the cause of failure of root canal treatment. Guava fruit and leaves (Psidium guajava) contain flavonoids, tannins, essential oils and saponins. The composition is able to act as an antibacterial. The purpose of this study is to compare the effect of guava leaf and fruit extracts on the growth of Enterococcus faecalis bacteria. This research is an experimental laboratory with Post Test Only Control Group Design. Inhibition test with the Discs Diffusion method, using the media Mueller Hinton Agar (MHA) with the method of spread (spread) and swab techniques. The results were analyzed with the Anova one-way test and then followed by the LSD test. The results showed there were growth inhibitions of Enterococcus faecalis after exposure to guava leaf and fruit extracts. The bacterial inhibition zone concentration increases with increasing concentration of the extract. Inhibition zone diameter that was formed in giving guava leaf extract concentration of 25\%, 50\%, 75\% and 100\% was $7.75 \mathrm{~mm}, 10.46 \mathrm{~mm}, 12.50 \mathrm{~mm}$ and $15.13 \mathrm{~mm}$. The mean diameter of inhibition zones formed on the administration of guava fruit extract concentrations of 25\%, 50\%, 75\% and $100 \%$ were 8.36 $\mathrm{mm}, 10.50 \mathrm{~mm}, 10.96 \mathrm{~mm}$ and $15.10 \mathrm{~mm}$. The inhibitory zone ability of $100 \%$ guava leaf concentration is almost equivalent to the ability of inhibitory zone of guava fruit 100\%.

Keyword: Enterococcus faecalis, guajava leaf extract, guajava fruit extract

\section{PENDAHULUAN}

Bakteri Enterococcus faecalis adalah bakteri Gram positif yang merupakan flora normal pada rongga mulut, saluran gastrointestinal dan saluran vagina yang bersifat fakultatif anaerob. ${ }^{1,2}$ Bakteri ini dapat bertahan hidup dalam berbagai MK | Vol. 3 | No. 2 | APRIL 2020 lingkungan termasuk $\mathrm{pH}$ alkali yang ekstrim. $^{3}$ Enterococcus faecalis sering disebut sebagai bakteri patogen penyebab kegagalan perawatan saluran akar karena mampu bertahan dalam saluran akar. ${ }^{1,4,5}$ Untuk mempertahankan gigi yang telah 
Rachmi Fanani Hakim : Perbandingan Daya Hambat Ekstrak Daun ...

terinfeksi oleh bakteri campuran pada saluran akar diperlukan perawatan saluran. Bahan antibakteri penting dalam perawatan saluran akar pada saat preparasi dan disinfeksi. $^{3,4}$ Melihat kelemahan obat disinfeksi perlu dikembangkan obat sterilisasi saluran akar yang berasal dari bahan alami serta memiliki daya antibakteri yang baik terhadap Enterococcus faecalis. ${ }^{6}$

Tanaman Jambu biji merupakan sumber bahan obat alami yang memiliki berbagai senyawa aktif., Jambu biji (Psidium guajava) mengandung flavonoid, minyak atsiri dan tanin yang memiliki kemampuan sebagai bahan anti bakteri terhadap bakteri Gram positif dan negatif. ${ }^{3}$ Penelitian ilmiah telah membuktikan jambu biji memiliki efek terapi, sebagai antibakteri, anti-oksidan, dan anti-inflamasi. ${ }^{8}$ Penelitian yang dilakukan oleh Hermawan (2013) menunjukkan bahwa ekstrak daun jambu biji pada konsentrasi 2\% memiliki kadar hambat minimal terhadap Streptococcus mutans dan kadar bunuh minimal pada konsentrasi 3,5\%. ${ }^{9}$ Penelitian Azizah (2004) menyebutkan bahwa ekstrak daun jambu biji dapat menghambat pertumbuhan Salmonella typhimurium. ${ }^{10}$ Ekstrak buah jambu biji menunjukkan aktivitas mikroba terhadap Escherichia coli, Staphylococcus aureus dan Shigella dysenteria. ${ }^{11}$ Hasil Penelitian
Rosidah (2012) menunjukkan diameter zona hambat ekstrak buah jambu biji terhadap Aeromonas hydrophila berkisar antara 6,5$11,5 \mathrm{~mm}^{12}$

\section{METODE PENELITIAN}

Penelitian ini merupakan penelitian eksperimental laboratorium dengan desain Post Test Only Control Group Design. Penelitian dilakukan pada bulan Juni 2018. Enterococcus faecalis didapat dari Laboratorium Mikrobiologi Fakultas Kedokteran Hewan Unsyiah. Ekstrak daun dan buah jambu biji (Psidium guajava) berasal dari perkebunan di Kecamatan Bukit, Bener Meriah, Aceh Tengah.

\section{Pembuatan Ekstrak Daun dan Buah Jambu Biji (Psidium guajava)}

Daun dan buah jambu biji (Psidium guajava) masing-masing sebanyak $2 \mathrm{~kg}$ ditimbang, dicuci bersih dengan air, ditiriskan lalu dikeringkan. Buah jambu dipotong kecil-kecil, lalu ditumbuk menggunakan lumpang dan alu selanjutnya sampel disimpan dalam toples. ${ }^{8,11}$ Daun dan buah jambu biji (Psidium guajava) diekstraksi dengan menggunakan metode maserasi dengan pelarut etanol $96 \%$. Selanjutnya dilakukan pengadukan kontinyu selama 30 menit, lalu didiamkan selama 24 
Rachmi Fanani Hakim : Perbandingan Daya Hambat Ekstrak Daun ...

jam pada suhu ruang. Diaduk kembali Setelah 24 jam dan didiamkan selama 24 jam lagi selanjutnya disaring. Pengadukan sampai pendiaman dan penyaringan larutan diulangi lagi agar zat aktif dapat tersari dengan baik oleh etanol. ${ }^{3}$ Penguapan etanol filtrat dengan evaporasi menggunakan vacum rotary evaporator pada suhu $70 \circ \mathrm{C}$ selama 1 jam, untuk mendapatkan ekstrak kental. ${ }^{3,11}$ Hasil Ekstrak daun dan buah Jambu Biji murni (100\%) diencerkan dengan akuades agar didapatkan konsentrasi yang diperlukan, kemudian dihomogenkan menggunakan vortex. ${ }^{3}$

\section{Kultur dan Uji Konfirmasi Enterococcus faecalis Kultur dilakukan dengan teknik goresan T (streak T).}

Kultur Enterococcus faecalis dilakukan pada media Mueller Hinton Agar (MHA). Cawan petri dibagi menjadi 3 bagian menggunakan spidol marker. Kultur diawali dengan memanaskan jarum ose dan ditunggu dingin, lalu mengambil 1 ose biakan murni untuk diinokulasi di daerah 1 , yaitu separuh cawan dengan goresan zigzag. Jarum ose dipanaskan kembali dan ditunggu hingga dingin, dilanjutkan dengan goresan zig-zag pada daerah 2 yang tegak lurus dengan goresan pertama, goresan zigzag pada daerah 3 selanjutnya dibuat tegak lurus terhadap goresan kedua.11,13 MK | Vol. 3 | No. 2 | APRIL 2020
Selanjutnya bakteri diinkubasi selama 24 jam pada suhu 37oC..$^{3,11,13}$ Pewarnaan Gram dilakukan untuk konfirmasi Enterococcus faecalis. ${ }^{16}$

Pembuatan Suspensi Enterococcus faecalis yang telah dibiakkan di media MHA, diambil dengan jarum ose lalu dimasukkan ke dalam tabung reaksi berisi 5 ml larutan Nutrient Broth. Selanjutnya atbung reaksi dihomogenkan dengan vortex. Larutan Mc. Farland 0,5 (1,5 x $10^{8}$ CFU/ml) digunakan untuk penyetaraan. ${ }^{5}$

\section{Uji Daya Hambat Ekstrak Daun dan} Buah Jambu Biji terhadap Pertumbuhan Bakteri Enterococcus faecalis.

Pengujian menggunakan metode Difusi Cakram dalam media Mueller Hinton Agar (MHA), dengan metode spread (sebar) dengan teknik swab. Cotton swab disuspensi Enterococcus faecalis ditekan ke bagian dinding tabung reaksi sampai tidak ada tetesan lagi. Cotton swab dioleskan secara menyeluruh pada permukaan media MHA dan ditunggu sampai kering. Kertas cakram yang telah direndam diletakkan pada ekstrak daun dan buah jambu biji dengan konsentrasi perlakuan $100 \%, 75 \%$, 50\%, dan $25 \%$, sampai cakram menyerap ekstrak dengan sempurna. ${ }^{15}$ Untuk mendapatkan wilayah jernih yang dibuat tidak berhimpitan 
Rachmi Fanani Hakim : Perbandingan Daya Hambat Ekstrak Daun ...

dibuat pengaturan jarak antara kertas cakram dengan tepi cawan yang cukup luas. Kertas cakram ditekan menggunakan pinset steril pada permukaan media. Inkubasi media pada suasana anaerob dengan suhu $37^{\circ} \mathrm{C}$ selama 24 jam. Pengukuran luas wilayah jernih tiap konsentrasi ekstrak daun dan buah jambu biji dilakukan setelah inkubasi 24 jam dengan menggunakan penggaris millimeter. Hasil penelitian diinterpretasikan berdasarkan klasifikasi oleh Ahn. ${ }^{4}$

Analisis statistik hasil penelitian dilakukan tabulasi data. Data yang diperoleh dianalisis dengan uji one-way Anova, dan uji lanjut Least Significant Difference (LSD) menggunakan aplikasi Statistical Package for the Social Scienses (SPSS) untuk mengetahui adanya pengaruh pemberian berbagai konsentrasi ekstrak daun dan buah jambu biji (Psidium guajava) terhadap pertumbuhan Enterococcus faecalis. ${ }^{4}$

\section{HASIL DAN PEMBAHASAN}

Penelitian ini bertujuan untuk membandingkan pengaruh ekstrak daun dan buah jambu biji (Psidium guajava) terhadap aktivitas bakteri Enterococcus faecalis. Peneliti menemukan bahwa ekstrak ekstrak daun dan buah jambu biji (Psidium guajava) memiiliki kemampuan daya hambat terhadap bakteri Enterococcus faecalis.
Hasil uji pengaruh ekstrak daun dan buah jambu biji terhadap pertumbuhan $E$. faecalis dilakukan dengan mengukur diameter zona hambat atau clear zone yang terbentuk di sekitar cakram pada berbagai konsentrasi serta kontrol negatif dan positif dalam penelitian ini dilakukan dengan tiga kali pengulangan, hasil pengukuran dapat dilihat pada Tabel 1.

Zona hambat rerata pada penelitian ekstrak daun jambu pada konsentrasi $25 \%$ adalah 7,76 $\mathrm{mm}$ merupakan zona hambat minimal pada kelompok percobaan penelitian ini. Pada konsentrasi 50\% - 75\% ekstrak daun jambu biji menunjukan daya hambat lemah yaitu 10,46 $\mathrm{mm}$ dan 12,50 mm. Pada konsentrasi ekstrak daun jambu biji $100 \%$ menunjukan zona hambat 15,13 $\mathrm{mm}$ masuk kategori daya hambat sedang. Kontrol negatif pada penelitian ini menggunakan akuades dengan hasil yang menunjukkan tidak terdapatnya zona hambat atau clear zone, sedangkan kontrol positif menggunakan $\mathrm{CHX} 2 \%$ memiliki daya hambat $17,13 \mathrm{~mm}$, kategori daya hambat sedang. Bila dibandingkan dengan konsentrasi ekstrak yang lainnya konsentrasi ekstrak daun jambu biji 100\% merupakan zona hambat terbesar yaitu sebesar $15,13 \mathrm{~mm}$. 
Rachmi Fanani Hakim : Perbandingan Daya Hambat Ekstrak Daun ...

Tabel 1 Hasil Uji Pengaruh Ekstrak Daun dan Buah Jambu Biji (Psidium guajava) terhadap Aktivitas E. faecalis

\begin{tabular}{|c|c|c|c|c|c|}
\hline \multirow{2}{*}{$\begin{array}{l}\text { Konsentrasi } \\
\text { bahan Uji }\end{array}$} & \multicolumn{3}{|c|}{ Zona Hambat (mm) } & \multirow{2}{*}{$\begin{array}{c}\text { Rerata } \\
\text { Zona } \\
\text { Hambat } \\
\text { (mm) }\end{array}$} & \multirow{2}{*}{$\begin{array}{c}\text { Kemampuan daya } \\
\text { hambat } \\
\text { (berdasarkan } \\
\text { klasifikasi Ahn) }\end{array}$} \\
\hline & U1 & $\mathrm{U} 2$ & U3 & & \\
\hline K (-) & 0 & 0 & 0 & 0 & Tidak ada \\
\hline B $25 \%$ & 8.6 & 8.7 & 8.5 & 8.6 & Tidak ada \\
\hline $\mathrm{B} 50 \%$ & 10.5 & 10.2 & 10.8 & 10.5 & Lemah \\
\hline $\mathrm{B} 75 \%$ & 11 & 10.7 & 11.2 & 10.96 & Lemah \\
\hline B100\% & 15.6 & 14.7 & 15.0 & 15.10 & Sedang \\
\hline D $25 \%$ & 7,8 & 7,5 & 8.0 & 7,76 & Tidak Ada \\
\hline D50\% & 10,6 & 10,1 & 10,7 & 10,46 & Lemah \\
\hline D75\% & 12,5 & 12.0 & 13.0 & 12,50 & Lemah \\
\hline D100\% & 15,2 & 14,7 & 15,5 & 15,13 & Sedang \\
\hline $\mathrm{K}(+)$ & 17,3 & 16,8 & 17,3 & 17,13 & Sedang \\
\hline
\end{tabular}

Hasil penelitian pada buah jambu biji menunjukkan zona hambat ekstrak buah jambu pada konsentrasi $25 \%$ reratanya 8,36 mm. Zona Hambat ini merupakan zona hambat minimal pada kelompok percobaan penelitian ini. Ekstrak buah jambu biji pada konsentrasi $50 \%$ - $75 \%$ menunjukan zona hambat $10,50 \mathrm{~mm}$ dan $10,96 \mathrm{~mm}$ memiliki daya hambat lemah. Ekstrak buah jambu biji pada konsentrasi $100 \%$ menunjukan zona hambat $15,10 \mathrm{~mm}$ memiliki daya hambat sedang. Kontrol negatif pada penelitian ini menggunakan akuades dengan hasil yang menunjukkan tidak terdapatnya zona hambat atau clear zone, sedangkan kontrol positif menggunakan $\mathrm{CHX} 2 \%$ memiliki daya hambat $17,13 \mathrm{~mm}$, memiliki kemampuan daya hambat pertumbuhan bakteri yang sedang. Bila dibandingkan dengan semua variable konsentrasi ekstrak hambatan bakteri terbesar terjadi pada konsentrasi ekstrak buah jambu biji 100\% yaitu 15,10 mm. Uji statistik pada penelitian ini menggunakan one way Anova. Hasil uji normalitas dan homogenitas varian data penelitian normal. Hasil uji one way Anova menunjukkan nilai $\mathrm{p}<0,05$, menunjukkan bahwa terdapat pengaruh dari kelompok uji terhadap pertumbuhan E. faecalis. Hasil uji lanjut menggunakan uji lanjut Least Significant Difference (LSD) menunjukkan bahwa adanya perbedaan bermakna pada 
Rachmi Fanani Hakim : Perbandingan Daya Hambat Ekstrak Daun ...

beberapa konsentrasi dan kelompok kontrol yang diuji dengan nilai $\mathrm{p}<0,05$.

Penelitian ini membandingkan pengaruh ekstrak daun dan buah jambu biji (Psidium guajava) terhadap aktivitas bakteri Enterococcus faecalis. Ekstrak daun dan buah jambu biji (Psidium guajava) diperoleh dengan menggunakan metode maserasi, dengan pertimbangan prosedur dan peralatan sederhana. Prosedur maserasi tidak menggunakan pemanasan sehingga bahan alam tidak terurai. ${ }^{15}$ Metode ini dilakukan dengan memasukkan bahan tanaman dan pelarut yang sesuai ke dalam wadah yang tertutup rapat pada suhu kamar. Setelah proses ekstraksi, pelarut kemudian dipisahkan dengan melakukan penyaringan sehingga didapat hasil ekstrak yang dibutuhkan.

\section{Bakteri Enterococcus faecalis} diperoleh dengan mengkultur bakteri menggunakan media MHA. Pewarnaan Gram dilakukan untuk mengkonfimasi hasil kultur Enterococcus faecalis. Hasil pewarnaan Gram menunjukkan bahwa terdapat koloni berwarna ungu, berbentuk coccus (bulat) dan tersusun seperti rantai. Gambaran ini sesuai dengan gambaran Enterococcus faecalis yaitu bakteri berbentuk stafilokokus dan positif terhap perwarnaan Gram. Perbedaan komposisi kimiawi dinding sel bakteri menyebabkan bakteri terwarnai ungu. Asam-asam ribonukleat pada sitoplasma bakteri Gram positif menyebabkan tebalnya lapisan peptidoglikan. Ikatan yang lebih kuat dengan kompleks ungu kristal violet terbentuk terhadap Sitoplasma bakteri membuat ikatan kimia tersebut tidak mudah dipecahkan. ${ }^{18}$

Penelitian ini menguji pengaruh ekstrak daun dan buah jambu biji terhadap aktivitas bakteri Enterococcus faecalis dengan metode difusi cakram. Pengujian dilakukan dengan cara mengukur diameter zona bening yang terbentuk pada media. Menurut Ahn dkk, kemampuan daya hambat zat terhadap bakteri dapat diklasifikasikan menjadi kemampuan lemah, kemampuan sedang dan kemampuan kuat. ${ }^{11}$

Pada hasil penelitian terlihat bahwa konsentrasi $25 \%$ ekstrak daun jambu biji tidak memiliki daya hambat Enterococcus faecalis dalam klasifikasi menurut Ahn yaitu $7,76 \mathrm{~mm}$ hal ini dikarenakan pada konsentrasi rendah hanya sedikit zat aktif yang terkandung sehingga menghasilkan daya hambat yang relatif rendah.3 Ekstrak daun jambu pada konsentrasi 50\% - 75\% menunjukkan daya hambat terhadap kultur Enterococcus faecalis dengan kemampuan daya hambat lemah, hal ini dikarenakan konsentrasi ekstrak yang rendah 
Rachmi Fanani Hakim : Perbandingan Daya Hambat Ekstrak Daun ...

mengandung sedikit zat aktif sehingga hanya sedikit saja kemampuan membunuh Enterococcus faecalis dan membuat daya hambat lemah. Konsentrasi $100 \%$ ekstrak daun jambu biji menunjukkan tingkat kemampuan daya hambat yang sedang yaitu $15,13 \mathrm{~mm}$, hal ini dikarenakan pekatnya konsentrasi ekstrak sehingga mampu menghambat pertumbuhan bakteri Enterococcus faecalis memberikan efek yang berarti. ${ }^{3,12}$

Penelitian ini menggunakan CHX $2 \%$ sebagai kontrol positif menghasilkan diameter zona hambat sebesar $17,13 \mathrm{~mm}$ memiliki kemampuan daya hambat pertumbuhan bakteri kategori sedang. Kontrol positif memiliki daya hambat terbesar pada penelitian ini. Klorheksidin $2 \%$ memiliki efek antibakterial terhadap bakteri Enterococcus faecalis dapat melisiskan sel mikroba., ${ }^{3,6}$ Kontrol negatif pada penelitian ini menggunakan akuades dengan hasil yang menunjukkan tidak terdapatnya zona hambat pada bakteri Enterococcus faecalis. Hasil penelitian pada buah jambu biji menunjukkan bahwa konsentrasi $25 \%$ ekstrak buah jambu biji tidak memiliki daya hambat Enterococcus faecalis dalam klasifikasi menurut Ahn yaitu 8,36 mm, hal ini dikarenakan pada konsentrasi rendah hanya sedikit mengandung zat aktif sehingga menghasilkan daya hambat yang relatif rendah. ${ }^{3}$ Ekstrak buah jambu terhadap kultur Enterococcus faecalis pada konsentrasi $50 \%$ - 75\% menunjukkan daya hambat lemah hal ini dikarenakan pada konsentrasi kandungan zat aktif sedikit sehingga hanya sedikit saja ekstrak yang mampu membunuh Enterococcus faecalis dan menyebabkan daya hambat yang lemah. ${ }^{3,14}$ Konsentrasi ekstrak buah jambu biji 100\% menunjukkan tingkat kemampuan daya hambat yang sedang yaitu 15,10 $\mathrm{mm}$ hal ini dikarenakan pekatnya konsentrasi ekstrak sehingga mampu menghambat pertumbuhan bakteri Enterococcus faecalis memberikan efek yang berarti. Terbentuknya zona hambat di sekitar cakram menunjukkan adanya kandungan senyawa antibakteri pada ekstrak daun jambu biji yang memiliki kandungan zat flavonoid, tanin, minyak atsiri dan saponin. Tiga senyawa antibakteri tersebut bekerja dengan metode beragam. Flavonoid dan minyak atsiri dapat mengganggu proses metabolisme mikroba, tannin dapat menghambat pertumbuhan mikroba dan saponin. ${ }^{19}$

Penelitian ini menggunakan CHX $2 \%$ sebagai kontrol positif menghasilkan diameter zona hambat sebesar 17,13 mm memiliki kemampuan daya hambat 
Rachmi Fanani Hakim : Perbandingan Daya Hambat Ekstrak Daun ...

pertumbuhan bakteri yang sedang. Kontrol positif memiliki daya hambat terbesar pada penelitian ini. Klorheksidin $2 \%$ memiliki efek antibakterial terhadap bakteri Enterococcus faecalis dapat melisiskan sel mikroba. Kontrol negatif pada penelitian ini menggunakan akuades menunjukkan tidak terdapatnya zona hambat pada bakteri E. Faecalis. $^{3,6}$

Hasil penelitian ini juga menunjukkan peningkatan persentase konsentrasi ekstrak menyebabkan meningkatnya diameter zona hambat bakteri, peningkatan ini disebabkan peningkatan kandungan zat aktif yang semakin banyak, sehingga dapat mempengaruhi zona hambat yang terbentuk. Penelitian ini sejalan dengan penelitian yang dilakukan oleh Denik Islamiyah (2010) yang menunjukkan peningkatan konsentrasi ekstrak buah jambu biji diikuti penigkatan zona hambat yang dibentuk. $^{12}$

Penelitian ini juga memperlihatkan ekstrak daun dan buah jambu biji $100 \%$ memiliki daya anti bakteri yang tertinggi dibanding konsentrasi lainnya. Zona radikal terbentuk mendekati rata-rata zona radikal klorheksidin 2\%. Banyak faktor yang mempengaruhi jalan dan hasil pada penelitian ini dikarenakan keterbatasan dalam penelitian. Faktor yang mempengaruhi sifat/kadar bahan aktif pada tumbuhan seperti faktor genetik atau sifat bawaan dari induk tanaman, seperti rasa, bau, dan komposisi kimia serta faktor lingkungan dari tanaman yang banyak mempengaruhi sifat/kadar bahan aktif pada tumbuhan seperti sinar matahari, temperatur, musim, serta tempat/daerah pertumbuhan. Faktor-faktor tersebut menyebabkan ekstrak jambu biji memiliki daya antibakteri yang sedikit lebih rendah dibandingkan dengan klorheksidin (CHX) 2\%. Penelitian yang telah dilakukan oleh Rizqina (2014) menyatakan bahwa, ekstrak daun jambu menghambat pertumbuhan Streptococcus mutans. ${ }^{13}$ Selain itu, Rosidah (2012) menyatakan ekstrak buah jambu biji berpotensi sebagai antibakteri terhadap bakteri Aeromonas hydrophila. ${ }^{14,18,19}$ Berdasarkan efektif kerjanya, senyawa antibakteri dibagi dua, yaitu senyawa antibakteri berspektrum luas dan berspektrum sempit. Senyawa antibakteri berspektrum luas efektif terhadap bakteri Gram positif dan Gram negatif, sedangkan senyawa antibakteri berspektrum sempit hanya efektif untuk bakteri Gram negatif atau Gram positif saja. ${ }^{12,20}$ Hasil penelitian yang diperoleh dari penelitian ini menunjukkan bahwa pada ekstrak daun dan buah jambu biji memiliki kandungan yang 
Rachmi Fanani Hakim : Perbandingan Daya Hambat Ekstrak Daun ...

berpotensi sebagai senyawa antibakteri berspektrum luas. Hal ini disebabkan pada kemampuannya menghambat pertumbuhan bakteri Gram positif maupun Gram negatif. ${ }^{12}$

Hasil uji statistik menggunakan oneway Anova menunjukkan ekstrak daun dan buah jambu biji (Psidium guajava.) memiliki pengaruh bermakna terhadap pertumbuhan Enterococcus faecalis dengan nilai $\mathrm{p}<0.05$. Hasil uji lanjut menggunakan Least Significant Difference (LSD) menunjukkan bahwa terdapatnya perbedaan bermakna di antara semua kelompok yang dianalisis kecuali perlakuan yang tidak terdapat perbedaan yang bermakna adalah konsentrasi buah $25 \%$ dan daun $25 \%$ dengan nilai $\mathrm{p} \geq 0.161$. Hal ini menunjukkan bahwa kemampuan zona hambat konsentrasi daun 25\% hampir setara dengan kemampuan zona hambat daun 25\%. Pada konsentrasi 50\% buah dengan daun $50 \%$ dengan nilai $\mathrm{p} \geq 0.161$ serta buah $50 \%$ dengan buah $75 \%$ dengan nilai $\mathrm{p} \geq 0.252$. Pada konsentrasi daun $100 \%$ dengan buah $100 \%$ memiliki nilai $\mathrm{p} \geq 0.280$. Hal ini menunjukkan bahwa kemampuan zona hambat konsentrasi daun jambu biji $100 \%$ hampir setara dengan kemampuan zona hambat buah jambu biji $100 \%$. Perbedaan tidak bermakna ini dapat disebabkan karena komposisi keduanya berbeda sehingga mempengaruhi pada perannya sebagai anti bakteri. Pada daun jambu biji mengandung saponin, flavonoid, tanin, terpenoid, alkaloid, dan steroid. ${ }^{20}$ Selain itu daun jambu biji juga mengandung kuersetin dalam kadar yang tinggi yaitu sebesar $61,71 \% .^{21}$ Flavonoid konsentrasi rendah mempunyai kemampuan merusak membran sitoplasma sehingga menyebabkan bocornya metabolit penting yang membuat sistem enzim bakteri menjadi inaktif. Flavonoid pada konsentrasi tinggi memiliki kemampuan merusak membran sitoplasma serta mengendapkan protein sel. ${ }^{22}$ Daun jambu biji kaya akan tannin, tannin mempunyai kemampuan anti bakteri melalui cara pengendapan protein, dan melalui reaksi dengan membran sel serta juga dengan menginaktivasi enzim bakteri. $^{3,12}$ Kandungan Fitokimia Buah jambu biji lainnnya polifenol, minyak atsiri (eugenol), saponin berkombinasi dengan oleanolat, flavonoid kuersetin, likopen, tanin, asam ursolat, asam psidiolat, asam kratogolat, asam oleanolat, dan asam guajaverin. Buah jambu biji juga mengandung vitamin C $183,5 \mathrm{mg} .{ }^{23}$ Vitamin C merupakan Anti Oksidan. Antioksidan merupakan zat yang mampu menghambat atau membuat penundaan oksidasi suatu molekul melalui mekanisme mengakhiri reaksi berantai, inisiasi serta propagasi. ${ }^{24}$ 
Rachmi Fanani Hakim : Perbandingan Daya Hambat Ekstrak Daun ...

\section{KESIMPULAN}

Ekstrak daun jambu biji (Psidium guajava) memiliki kemampuan menghambat pertumbuhan Enterococcus faecalis. Ekstrak buah jambu biji pada konsentrasi $50 \%$ adalah 10,46 mm, konsentrasi $75 \%$ adalah 12,50 $\mathrm{mm}$ dapat menghambat Enterococcus faecalis dengan kemampuan daya hambat kategori lemah, dan konsentrasi $100 \%$ adalah 15,13 mm. Ekstrak buah jambu biji pada konsentrasi $50 \%$ adalah $10,50 \mathrm{~mm}$, konsentrasi $75 \%$ adalah $10,96 \mathrm{~mm}$ dapat menghambat Enterococcus faecalis dengan kemampuan daya hambat kategori lemah, dan konsentrasi $100 \%$ adalah $15,10 \mathrm{~mm}$. Ekstrak daun dan buah dengan konsentrasi $100 \%$ dapat menghambat dengan kategori sedang. kemampuan zona hambat konsentrasi daun jambu biji 100\% hampir setara dengan kemampuan zona hambat buah jambu biji 100\%.

\section{DAFTAR PUSTAKA}

1. Hakim RF, Fakhrurrazi, Ferisa W. Pengaruh Air Rebus Daun Salam (Euhenia polyantha wight) Terhadap Pertumbuhan Entrococcus faecalis. Journal of Syiah Kuala Dentistry Society . 2016;1(1):21-8.
2. Mulyawati E. Peran Bahan Disinfeksi Pada Perawatan Saluran Akar. Maj Ked Gi. 2011;18(2):205-8

3. Sofiani E, Dhita A M. Perbedaan Daya Antibakteri antara Klorheksidin Digglukonat 2\% dan Ekstrak Daun Jambu Biji (Psidium guajava Linn) Bebagai konsentrasi (Tinjauan terhadap Enterococus Faecalis. IDJ. 2014;3(1):33-4

4. Soraya C, Sunnanti,Vivi M. Efek Antibakteri Batang Serai (Cymbopogon citratus) Terhadap Pertumbuhan Enterococcus faecalis. Cakrodonya Dent Journal. 2016;8(2):6973

5. Lucia FC, Soegijanto, Rima PS. Daya Hambat Alpukat (Percea americana, Mill.) Terhadap Pertumbuhan Entrococcus faecalis. Denta Majalah Kedokteran Gigi. 2014;8(1):1-10

6. Fadhilah A, Kristanti, Henu S. Daya hambat Ekstrak Nannochloropsis oculata Terhadap Pertumbuhan Bakteri Enterococcus faecalis. Denta Majalah Kedokteran Gigi. 2014;8(1):23-30

7. Permatasari A. Uji Efek Penurunan Kadar Glukosa Darah Ekstrak Etanol 70\% Buah Jambu Biji (Psidium guajava L) Pada Kelinci Jantan Lokal. Surakarta: Fakultas Farmasi Universitas 
Rachmi Fanani Hakim : Perbandingan Daya Hambat Ekstrak Daun ...

Muhammadiyah Surakarta. 2008;

Skripsi.p 4-5.

8. Febrianti N, Mila IR, Irfan Y, Risanti D. Perbandingan Aktivitas Antioksidan Buah Pepaya (Carica papaya L.) dan Buah Jambu Biji Merah (Psidium guajava L.). Prosiding Seminar Nasional Pendidikan Biologi dan Pusat Studi Lingkungan dan Kependudukan Universitas Muhammadiyah Malang. 2016;p 1217-8

9. Rizqina N. Uji Efektifitas Antibakteri Infusum Daun Jambu Biji (Psidium guajava) Terhadap Pertumbuhan Bakteri Penyebab Karies Streptococcus mutans Secara Invitro. Padang: Fakultas Kedokteran Gigi Universitas Andalas. 2014; Skripsi.p 12-4

10. Ajizah A. Sensitivitas Salmonella typhimurium Terhadap Ekstrak Daun Jambu Biji (Psidium guajava). Bioscientiae. 2004;1(1):31-3

11. Mubarak Z, Chismirina S, Daulay H H. Aktivitas Antibakteri Ekstrak Propolis Alami dari Sarang Lebah Terhadap Pertumbuhan Enterococcus faecalis. Journal of Syiah Kuala Dentistry Society . 2016;1(2):175-86

12. Rosidah, Wila MA. Potensi Ekstrak Jambu Biji Sebagai Antibakterial untuk Menanggulangi Serangan Bakteri

Aeromonas hydrophila Pada Ikan Gurame ( Osphronemus Gouramy lacepede). J Akuatika. 2012;1(3):19-26

13. Hafidhah N, Hakim RF, Fakhrurrazi. Pengaruh Ekstrak Biji Kakao (Theobroma cacao L.) Terhadap Pertumbuhan Enterococcus faecalis Pada Berbagai Konsentrasi. J Caninus Dentistry. 2017;2(2):92-6 14. Suarsa N, Setiawan K. Tanaman Obat: Sembuhkan Penyakit untuk Sehat. Denpasar: Swasta Nulus. 2015. P24-8

14. Dahlan MS. Statistik untuk Kedokteran dan Kesehatan: Penerbit Salemba; 2011:88-95

15. Susanti AD, Ardiana D, Gumelar P, Bening G. Polaritas Pelarut sebagai Pertimbangan dalam Pemilihan Pelarut untuk Ekstraksi Minyak Bekatul dari Bekatul Varietas Ketan (Oriza sativa glatinosa). J.Simposium Nasional 2012:8-13

16. Sunatmo TI. Eksperimen Mikrobiologi dalam Laboratorium. Jakarta: Ardy Agency. 2009. p. 23

17. Adnyana I. K., Yulinah E, Sigit J. Efek Ekstrak Jambu Biji Daging Buah Putih dan Jambu Biji Daging Buah Merah Sebagai Antidiare. Acta Pharmaceutica Indonesia. 2004;29(1):39 
Rachmi Fanani Hakim : Perbandingan Daya Hambat Ekstrak Daun ...

18. Broto W. Teknologi Penanganan Pasca Panen Buah untuk Pasar. Jakarta:Departemen Pertanian. 2009. P. 37 20. Misrullaoh A, Rosiani E, Liawati I, Kartika A. Uji Daya Hambat Daun Jambu Biji Putih dan Merah terhadap Pertumbuhan Bakteri Lactobacillus acidophilus. Publikasi Ilmiah Unwahas. 2017.P12-5

19. Satiyarti R B, Yana Y, Dan Fatimatuzzahra. Penggunaan Ekstrak Daun Jambu Biji (Psidium Guajava L.) Sebagai Ovisida Keong Mas (Pomacea canaliculata L.). al-Kimiya, Vol. 6, No. 1 (32-35). 2019. 32-35

20. Dwitiyanti. Daun Jambu Biji (Psidium guajava L.) sebagai Antikanker Payudara. Pharm Sci Res August .2015 (Vol. 2 No. 2). 79-88

21. Ruhana Afifi 1), Euis Erlin2). Uji Anti Bakteri Ekstrak Daun Jambu Biji
(Psidium Guajava L) Terhadap Zona Hambat

Bakteri Jerawatpropionibacterium Acnes Secara In Vitro. Jurnal Kesehatan Bakti Tunas Husada.2017. Volume 17 Nomor 2. 321-330

22. Revika Rachmaniar, Haruman Kartamihardja, Merry . Pemanfaatan sari buah jambu biji merah (psidium guajava linn.) Sebagai antioksidan dalam bentuk granul effervescent. 2016 Indonesian Journal of Pharmaceutical Science and Technology Vol.V, No.1, 7-20

23. Helmina Br. Sembiring. Aktivitas Antibakteri dan Antioksidan Minyak Atsiri Daun Asam Jungga (Citrus jambhiri Lush). Chimica et Natura $\operatorname{Acta}(2018)$ Vol. 6 No. 1: 19-24 